\title{
STRATEGY DEVELOPMENT AND IMPLEMENTATION OF GOOD CORPORATE GOVERNANCE (GCG) ON BUMN AND BUMD IN INDONESIA
}

\author{
Iwan Nuryan \\ Doctoral Student of Business Administration Faculty of Social \\ and Political Science University of Padjadjaran \\ Email:iwannuryan@gmail.com
}

\begin{abstract}
Good Corporate Governance (GCG) is a important measure in the corporation an business practice. Some fact that showed lowed rank in the implementation of GCG in Indonesia, had been one of important factors that caused economic crisis and slow face of economic growth in Indonesia, This is had been a trigger to all stakeholders to continue encourage implementation of GCG in Indonesia. There are four important principal in GCG that now continue to encourage, fairness, transparency, accountability, and responsibility.

At the level of practice, the application of GCG in Indonesia, especially in BUMN and BUMD is still very low. Some of the obstacles that hinder the implementation of GCG in Indonesia, especially in $B U M N$ and BUMD are the internal constraints, external constraints, and constraints of ownership. To overcome the obstacles it needs to be stressed to continue to raise awareness of all stakeholders about the important of GCG implementation, strengthening the legal basis of GCG implementation, strengthening government system reform until clean government that free from corruption had been establish, and do some reform throughout the business corporation that runs in Indonesia.
\end{abstract}

Keywords : strategy, GCG, BUMN, BUMD

\section{STRATEGI PENGEMBANGAN DAN PENERAPAN GOOD CORPORATE GOVERNANCE (GCG) BAGI BUMN DAN BUMD DI INDONESIA}

\begin{abstract}
ABSTRAK
Good Corporate Governance (GCG) merupakan sebuah instrumen penting dalam praktek bisnis dan perusahaan. Fakta menunjukkan bahwa rendahnya penerapan GCG di Indonesia telah menjadi salah satu faktor penting terjadinya krisis ekonomi di Indonesia serta lambatnya pertumbuhan ekonomi di Indonesia. Hal ini telah menjadi pendorong berbagai pihak untuk terus mendorong penerapan GCG di Indonesia. Empat prinsip penting dalam GCG yang saat ini terus didorong untuk diterapkan adalah kewajaran, transparansi, akuntabilitas, dan responsibilitas. Pada tataran praktek, penerapan GCG di Indonesia, khususnya pada BUMN dan BUMD masih sangat rendah. Beberapa kendala yang menghambat penerapan GCG di Indonesia, khususnya pada BUMN dan BUMD adalah kendala internal, kendala eksternal, dan kendala kepemilikan. Untuk mengatasi berbagai kendala tersebut maka perlu ditekankan untuk terus meningkatkan kesadaran berbagai pihak akan pentingnya penerapan GCG, memperkuat dasar hukum penerapan GCG, mereformasi sistem pemerintahan hingga terciptanya praktek clean government yang bebas KKN serta reformasi di seluruh korporasi bisnis yang berjalan di Indonesia.
\end{abstract}

Kata kunci : strategy, GCG, BUMN, BUMD 


\section{PENDAHULUAN}

Krisis moneter yang melanda hampir ke seluruh negara, terutama di negara-negara berkembang seperti di kawasan Asia, termasuk Indonesia, terjadi sejak dua dasa warsa terakhir ini.

Pada sektor penyelenggaraan negara dan pemerintahan, terjadi situasi yang tidak kondusif, sehingga tidak tercapainya checks and balances antara eksekutif, legislatif dan yudikatif. Sehingga tidak berjalan kontrol sosial dan institusi pengawasan lainnya dan marak praktek Korupsi, Kolusi dan Nepotisme (KKN).

Pada sektor pelaku ekonomi, para pelaku ekonomi swasta pada umumnya menunjukkan kesalahan manajemen, sehingga tidak memiliki keunggulan atau daya saing yang kuat di pasar internasional, bahkan kondisi mental perusahaan masuk dalam kualifikasi tidak sehat.

Salah satu permasalahan utama yang menjadi pemicu krisis keuangan ini adalah rendahnya kinerja dan daya saing dari perusahaan milik negara dan perusahaan milik swasta, sebagai akibat dari tidak efektifnya penyelenggaraan egara/pemerintahan dan pembangunan secara nasional.

Berpijak dari kondisi ini, maka salah satu strategi dalam mencari solusi yang sampai saat ini sedang aktual, yaitu memberdayakan korporasi, baik perusahaan milik pemerintah maupun swasta, melalui implementasi Good Corporate Governance secara nyata. Efektivitas suatu sistem Corporate Governance tergantung pada kerangka legal, struktur kepemilikan dan sifat pasar.

\section{TINJAUAN PUSTAKA}

Korporasi moderen berkembang menjadi kelompok korporasi (konglomerasi) dengan skala dan kompleksitas tinggi. Sebuah entitas korporasi dapat memiliki saham perusahaan. Kecenderungan masa kini di banyak negara, termasuk Indonesia, adalah privatisasi (penjualan saham BUMN menjadi korporasi swasta yang menguntungkan).
Perkembangan isu Corporate Governance yang tadinya hanya bersifat marginal, kini menjadi isu sentral, oleh sebab itu, dibutuhkan pemahaman yang memadai tentang Corporate Governance.

Pengertian Corporate dan Corporate Governance, antara lain: IICG (The Indonesian Institute of Corporate Governance) dalam Purwoko, (2012:4) mendefenisikan Corporate Governance sebagai berikut: merupakan proses dari struktur yang diterapkan dalam menjalankan perusahaan dengan tujuan utama meningkatkan nilai pemegang saham dalam jangka panjang dengan tetap memperhatikan kepentingan stakeholders yang lain.

Menurut Tunggal (2013:149) Corporate Governance adalah sistem dan struktur untuk mengelola perusahaan dengan tujuan meningkatkan nilai pemegang saham (shareholders) seperti kreditor, supplier, asosiasi usaha, konsumen, pekerja, pemerintah dan masyarakat luas. Menurut Organization for Economic Coorporation and Development (OECD) Tangkilisan (2003:11) Corporate Governance adalah sekumpulan hubungan antara pihak lain yang mempunyai kepentingan dengan perusahaan. Menurut Purwoko (2012:4), pengertian tentang Corporate Governance dapat dimasukkan dalam dua kategori. Kategori pertama, lebih condong pada serangkaiaan pola perilaku perusahaan yang diukur melalui kinerja, pertumbuhan, struktur pembiayaan, perlakuan terhadap para pemegang saham, dan stakeholders.

Kategori kedua, lebih melihat pada kerangka secara normatif, yaitu segala ketentuan hukum baik yang berasal dari sistem hukum, sistem peradilan, pasar keuangan dan sebagainya yang mempengaruhi perilaku perusahaan Good Corporate Governance merupakan suatu aturan mengenai pengelolaan perusahaan yang perlu diterapkan pada setiap perusahaan terutama perusahaan publik (BUMN). Menurut Forum for Corporate Governance in Indonesia (FCGI) pengertian Corporate Governance adalah: "Seperangkat peraturan yang mengatur hubungan antara pemegang saham, pengurus, pihak kreditur,pemerintah, karyawan serta para pemegang kepentingan interen dan eksteren 
lainnya sehubungan dengan hak-hak dan kewajiban mereka, atau dengan kata lain suatu sistem yang mengarahkan dan mengendalikan perusahaan. Tujuan Corporate Governance ialah untuk menciptakan pertambahan nilai bagi semua pihak pemegang kepentingan".

Berdasarkan pengertian-pengertian tersebut, bisa disebutkan bahwa Governance adalah sistem, proses dan seperangkat peraturan yang dimaksudkan untuk mengatur hubungan dan mencegah terjadinya kesalahan signifikansi dalam strategi korporasi dan untuk memastikan kesalahan yang terjadi dapat segera diperbaiki.

Prinsip-Prinsip Good Corporate Governance (Sedarmayanti,2012) menyebutkan bahwa OECD telah mengembangkan prinsip GCG dan dapat diterapkan secara luwes sesuai dengan keadaan, budaya dan tradisi masing-masing negara yang meliputi:

1. Fairness (Kewajaran)

Perlakuan yang sama terhadap pemegang saham minoritas dan pemegang saham asing, dengan keterbukaan informasi yang penting serta melarang pembagian untuk pihak sendiri dan perdagangan saham oleh orang dalam.

2. Disclosure dan Transparency (Transparansi) Hak pemegang saham dalam pengambilan keputusan mengenai perubahan mendasar atas perusahaan.

3. Accountability (Akuntabilitas)

Pengawasan efektif berdasarkan keseimbangan kekuasaan antar manajer, pemegang saham, dewan komisaris, dan auditor merupakan bentuk pertanggung jawaban manajemen kepada perusahaan dan pemegang saham.

4. Responsibility (Responsibilitas)

Kerja sama yang aktif antara perusahaan dan pemegang kepentingan dalam menciptakan kekayaan, lapangan kerja, dan perusahaan yang sehat dari aspek keuangan.

Sementara itu prinsip GCG menurut OECD mencakup lima bidang utama, yaitu:

1. Hak pemegang saham dan perlindungannya

2. Peran karyawan dan pihak yang berkepentingan
3. Pengungkapan yang akurat dan tepat waktu serta transparansi

4. Tanggung jawab dewan komisaris maupun direksi terhadap perusahaan

5. Perlakuan yang setara, transparansi, akuntanbilitas, dan reponsibilitas

Pemerintah memainkan peranan sentral dalam membentuk kerangka kerja legal, institusional dan pembuatan kebijakan di mana dalam kerangka kerja ini Governance System dikembangkan.

Corporate Governance membutuhkan perubahan pikiran atau paradigma yang secara mendasar mengubah budaya korporasi (nilai, norma, mental, dan perilaku korporasi). Maka Corporate Policy untuk berbagai aspek dalam korporasi, mulai dari manajemen risiko, manajemen isu lingkungan, kebijakan investasi dan pendanaan, kebijakan dan pengembangan sumber daya manusia. Perusahaan di Indonesia berada dalam lingkaran kompetisi global yang selalu harus menjadi lebih kompetitif terhadap pesaing. Bila pesaing global menjadi lebih efisien dan efektif dalam proses bisnisnya melalui penerapan IT tepat guna, maka perusahaan di Indonesia harus dapat segera mengimbanginya

\section{METODE PENELITIAN}

Penelitian dalam kajian ini menggunakan metode penelitian deskriptif, yaitu sebuah penelitian yang bertujuan untuk memberikan atau menjabarkan suatu keadaan atau fenomena yang terjadi saat ini dengan menggunakan prosedur ilmiah untuk menjawab masalah secara aktual (Sugiyono, 2011). Dengan demikian penelitian ini berusaha untuk menggambarkan fenomena penerapan GCG pada BUMN dan BUMD di Indonesia secara ilmiah, untuk kemudian didapat berbagai permasalahan aktual yang menghambat penerapan GCG di Indonesia.

Data-data yang berkaitan dengan penelitian ini diperoleh dengan analisis terhadap dokumendokumen yang ada seperti buku-buku ilmiah, dokumen kebijakan organisasi, dan peraturan perundang-undangan. 
Data yang digunakan dalam penelitian ini adalah data sekunder. Data sekunder diambil dari penelitian dokumen/produk kebijakan pemerintah maupun BUMN/BUMD serta dokumen-dokumen berita. Analisis yang digunakan adalah pendekatan kualitatif secara mendalam.

\section{HASIL DAN PEMBAHASAN}

\section{Corporate Governance di Indonesia}

Corporate Governance juga telah menjadi salah satu isu penting bagi pelaku usaha di Indonesia. Isu corporate governance dilatarbelakangi oleh permasalahan yang terkait dengan kecenderungan di industri pasar modal, korporasi, pasar, audit dan tuntutan akan transparansi dan independensi, dan krisis finansial di Asia.

Penerapan GCG dapat meningkatkan nilai perusahaan. Corporate Governance yang buruk menurunkan tingkat kepercayaan investor, lemahnya praktik Good Governance merupakan faktor yang memperpanjang krisis ekonomi di suatu negara.

Kementerian BUMN maupun Badan Pengawas Pasar Modal, dan Bursa Efek Jakarta, telah mewajibkan BUMN dan Emiten untuk menerapkan kebijakan GCG yang bertujuan menciptakan kepastian hukum yang bermuara kepada perlindungan investor dan masyarakat.

Penerapan GCG tidak dapat dilakukan secara parsial, dibutuhkan pendekatan secara holistik dan mendasar. Secara legal dibutuhkan hukum yang mendukung penerapannya.

Dalam menghadapi masalah ini pemerintah cukup responsif dengan ditetapkannya UndangUndang No. 19 Tahun 2003 tentang BUMN (Pasal 5 ayat 3), Instruksi Presiden No.5 tahun 2004 dan Keputusan Menteri Negara Badan Usaha Milik Negara No. KEP.117/M-MBU/2002 tanggal 01 Agustus 2002 tentang Penerapan Praktek Good Corporate Governance Pada Badan Usaha Milik Negara (BUMN) yang diperbarui menjadi Peraturan Menteri Negara BUMN No: PER-01/MBU/2011 tentang Penerapan Tata Kelola Perusahaan Yang Baik (Good Corporate Governance) pada Badan Usaha Milik Negara.
Faktanya, penerapan GCG pada BUMN masih rendah. Sejauh ini GCG di BUMN belum menjadi budaya perusahaan. Implementasi GCG pada hakikatnya adalah menjadi budaya perusahaan. Apabila implementasi GCG pada BUMN sangat rendah maka menunjukkan bahwa GCG belum menjadi budaya perusahaan, tidak membudaya membuka peluang terjadinya kecurangan.

Penerapan GCG pada BUMD pun secara normatif dan hukum sudah menjadi kewajiban. Pada tahun 2014, telah terbit Undang-Undang Nomor 23 Tahun 2014 tentang Pemerintah Daerah. Dalam UU tersebut BUMD disebutkan sebagai badan usaha yang seluruh atau sebagian besar modalnya dimiliki oleh daerah. Bentuk dari BUMD menurut UU tersebut dapat berupa Perusahaan Umum Daerah (seluruh modalnya dimiliki oleh satu daerah) dan Perusahaan Perseroan Daerah (berbentuk PT dengan saham seluruhnya atau paling sedikit $51 \%$ dimiliki oleh satu daerah). Dalam Pasal 343 UU No. 23 Tahun 2014 diatur secara umum tentang penerapan GCG secara umum pada BUMD.

BUMD yang berbentuk perusahaan umum daerah, pengelolaannya harus tunduk pada Peraturan Daerah tempat BUMD tersebut berada. Pengawasan dan pembinaan dari BUMD bentuk ini dilakukan oleh Kepala Daerah selaku wakil daerah sebagai pemilik modal, direksi, dan dewan pengawas. Kepala Daerah bisa melakukan intervensi terhadap kebijakan atau strategi yang diambil oleh BUMD untuk kepentingan daerahnya. Jadi, keseriusan dalam penerapan GCG untuk BUMD bentuk ini sangat bergantung pada komitmen dari Pemerintah Daerah tempat BUMD tersebut bernaung. Sedangkan untuk BUMD yang berbentuk Perusahaan Perseroan Daerah diwajibkan untuk tunduk pada Undangundang Nomor 40 Tahun 2007 tentang Perseroan Terbatas.

Dengan beberapa dasar hukum tersebut, diketahui bahwa sudah seharusnya BUMD, baik yang berbentuk perseroan terbatas atau tidak, menerapkan GCG. Permasalahan yang muncul kemudian adalah masih kurangnya kesadaran para pemimpin daerah tentang pentingnya penerapan GCG pada BUMD dalam rangka 
menciptakan BUMD yang sehat dan dapat berkembang dengan baik, sehingga mampu memberikan sumbangan PAD yang signifikan bagi daerah.

Saat ini, tidak hanya pemerintah saja yang mulai merasakan pentingnya menerapkan GCG pada perusahaan, khususnya BUMN dan BUMD, akan tetapi masyarakat umum pun sudah mulai berpartisipasi aktif mendorong penerapan GCG pada BUMN dan BUMD. Hal tersebut ditunjukan dengan kemunculan berbagai forum dan organisasi berbasis masyarakat dan perusahaan yang secara aktif mendorong penerapan GCG di Indonesia.

Sebuah bisnis tidak hanya dijalankan dengan modal uang saja, tetapi juga dengan tanggung jawab dan moralitas perusahaan terhadap stakeholders dan masyarakat. Oleh karena itulah, penerapan GCG yang menjadi sebuah prinsip dasar pengelolaan perusahaan berdasarkan tanggung jawab dan moralitas, menjadi hal yang sangat mendesak untuk terus didorong penerapannya di Indonesia.

Komite Nasional mengenai kebijakan Corporate Governance (National Committee on Corporate Governance/NCCG) pada Agustus 1999 mengidentifikasi sebanyak 13 bidang penting yang memerlukan pembaharuan. Selanjutnya, NCCG pada Maret 2001 menyusun dan menerbitkan Pedoman Good Corporate Governance (Code for Good Corporate Governance) yang menyebutkan bahwa dalam menerapkan GCG, terdapat beberapa pedoman umum yang harus dipahami dan dimengerti lebih lanjut. Pedoman GCG tersebut diidentifikasikan menjadi 13 bidang yang berisi:

1) Hak dan tanggung jawab pemegang saham.

2) Fungsi, tugas dan kewajiban dewan komisaris.

3) Fungsi, tugas dan kewajiban dewan direksi.

4) Sistem audit, termasuk peran auditor eksternal dan komite audit.

5) Fungsi, tugas dan kewajiban sekretaris perusahaan.

6) Hak stakeholders, dan akses kepada informasi yang relevan.

7) Keterbukaan yang tepat waktu dan akurat.
8) Kewajiban para komisaris dan direksi untuk menjaga kerahasiaan.

9) Larangan penyalahgunaan informasi oleh orang dalam.

10) Etika berusaha.

11) Ketidakpatutan pemberian donasi politik.

12) Kepatuhan kepada peraturan perundangundangan tentang proteksi kesehatan, keselamatan kerja, dan kelestarian lingkungan.

13) Kesempatan kerja yang sama bagi karyawan.

\section{Tantangan Penerapan GCG di Indonesia}

Perusahaan-perusahaan di Indonesia belum mampu melaksanakan corporate governance dengan sungguh-sungguh sehingga perusahaan mampu mewujudkan prinsip-prinsip GCG dengan baik. Hal ini disebabkan oleh adanya sejumlah kendala yang dihadapi oleh perusahaanperusahaan tersebut pada tataran implementasi. Kendala ini dapat dibagi tiga, yaitu kendala internal, kendala eksternal, dan kendala yang berasal dari struktur kepemilikan.

Kendala internal meliputi kurangnya komitmen dari pimpinan dan karyawan perusahaan, rendahnya tingkat pemahaman dari pimpinan dan karyawan perusahaan tentang prinsip-prinsip GCG, kurangnya panutan atau teladan yang diberikan oleh pimpinan, belum adanya budaya perusahaan yang mendukung terwujudnya prinsip-prinsip GCG, serta belum efektifnya sistem pengendalian internal (Djatmiko, 2004).

Kendala eksternal dalam pelaksanaan corporate governance terkait dengan perangkat hukum, aturan dan penegakan hukum (lawenforcement). Indonesia tidak kekurangan produk hukum. Secara implicit ketentuan-ketentuan mengenai GCG telah ada tersebar dalam UUPT, Undang-undang dan Peraturan Perbankan, Undang-undang Pasar Modal dan lain-lain. Namun penegakannya oleh pemegang otoritas, seperti Bank Indonesia, Bapepam, BPPN, Kementerian Keuangan, BUMN, bahkan pengadilan sangat lemah.

Baik kendala internal maupun kendala eksternal sama-sama penting bagi perusahaan, 
namun demikian, jika kendala internal bisa dipecahkan maka kendala eksternal akan lebih mudah diatasi (Djatmiko, 2004).

Kendala yang ketiga adalah kendala yang berasal dari struktur kepemilikan. Berdasarkan persentasi kepemilikan dalam saham, kepemilikan terhadap perusahaan dapat dibedakan menjadi dua, yaitu kepemilikan yang terkonsentrasi dan kepemilikan yang menyebar. Kepemilikan yang terkonsentrasi terjadi pada saat suatu perusahaan dimiliki secara dominan oleh seseorang atau sekelompok orang saja $(40,00 \%$ atau lebih). Kepemilikan yang menyebar terjadi pada saat suatu perusahaan dimiliki oleh pemegang saham yang banyak dengan jumlah saham yang kecil-kecil (satu pemegang saham hanya memiliki saham sebesar 5\% atau kurang).

Salah satu dampak negatif yang ditimbulkan oleh struktur kepemilikan adalah perusahaan tidak dapat mewujudkan prinsip keadilan dengan baik karena pemegang saham yang terkonsentrasi pada seseorang atau sekelompok orang dapat menggunakan sumberdaya perusahaan secara dominan sehingga dapat mengurangi nilai perusahaan. Sama seperti halnya kendala eksternal, dampak negatif yang ditimbulkan dari struktur kepemilikan dapat diatasi jika perusahaan memiliki sistem pengendalian internal yang efektif, seperti mempunyai sistem yang menjamin pendistribusian hak-hak dan tanggung jawab secara adil di antara berbagai partisipan dalam organisasi (Dewan Komisaris, Dewan Direksi, manajer, pemegang saham, serta pemangku kepentingan lainnya), dan dampak negatif ini juga akan hilang jika dalam stuktur organisasinya, perusahaan mempunyai Komisaris Independen dengan jumlah tertentu dan memenuhi kualifikasi yang ditentukan (syarat-syarat yang ditentukan untuk menjadi Komisaris Independen).

\section{SIMPULAN}

Keterpurukan perekonomian Indonesia telah mempengaruhi berbagai aspek kehidupan. Penyebab utama krisis ekonomi ini bukan dipengaruhi oleh berbagai indikator nasional juga faktor lingkungan eksternal. Tidak jalannya penyelenggaraan secara baik diawali dengan tidak berfungsinya checks \& balances. Pengawasan dari mulai lembaga tertinggi negara, lembagalembaga pemerintahan, bahkan masyarakat, tidak berfungsi secara efektif.

Dampak negatif yang merugikan bangsa ini yaitu maraknya praktek tidak sehat, baik di instansi pemerintah, swasta, maupun masyarakat sehingga budaya Korupsi, Kolusi, dan Nepotisme berakar dan berkembang secara kronis.

Permasalahan yang melanda bangsa ini, dipengaruhi oleh berbagai faktor eksternal, seperti: pengaruh berbagai indikator ekonomi secara internasional dan rapuhnya berbagai indikator internal yang menyangkut tata kelola perusahaan baik swasta maupun negeri.

Persyaratan utama penerapan GCG, yaitu terciptanya Good Governance (kepemerintahan yang baik). Penerapan praktik GCG akan memberi suatu nilai perusahaan dalam arti seluasluasnya, baik dalam meningkatkan kinerja keuangan, memperkecil resiko perusahaan yang akan timbul, meningkatkan daya saing, sehingga meningkatkan kepercayaan investor, stakeholder dan masyarakat. 


\section{DAFTAR PUSTAKA}

Djatmiko, Rahmat Dwi. 2004. Manajemen Stratejik. Malang: UMM Press.

Sedarmayanti, 2012. Good Governance dan Good Corporate Governance. Mandar Maju: Bandung.

Sugiyono, 2008. Metode Penelitian Kuantitatif, Kualitatif dan $R \& D$. Bandung: ALFABETA

Tangkilisan, Hessel Nagis, 2003. Manajemen Keuangan Bagi Analisis Kredit Perbankan: Mengelola Kredit Berbasis Good Corporate Governance. Balairung \& Co., Yogyakarta

Tjiptono, Fandi, 1997. Strategi Pemasaran. Penerbit Andi: Yogyakarta.

Tunggal, Amin Wijaya Tunggal, 2013. Memahami Konsep Corporate Governance. Jakarta: Havarindo

The IICG, 2011. Good Corporate Governance dalam Perspektif Risiko. Program Tahunan Riset dan Pemeringkatan Penerapan GCG di Indonesia. IICG: Jakarta.

Purwoko, Sigit, 2012. Pengaruh Good Corporate Governance Terhadap Kinerja Perusahaan Non Perbankan yang Terdaftar di BEI, Jurnal of Economic, Universitas Gunadarma, Jawa Barat, didownload dari http://www.gunadarma.ac.id 
